\title{
PENGARUH PROGRAM LIMBAT (LIMBAH SEHAT) TERHADAP KUALITAS KESEHATAN MASYARAKAT PEDESAAN
}

\author{
The Effect of LIMBAT (Limbah Sehat) on Rural Community Health Quality \\ Anggie Pradana Putri ${ }^{1}$, Tri Yuniarti ${ }^{2}$, Herry Susanto ${ }^{3}$ \\ ${ }^{1,2}$ STIKES Mamba'ul 'Ulum Surakarta \\ ${ }^{3}$ Universitas Islam Sultan Agung Semarang \\ (anggie.pputri@gmail.com)
}

\begin{abstract}
ABSTRAK
Latar Belakang : Indonesia Sehat yang paripurna berada dalam perjalanan realisasinya. Salah satu program yang dicanangkan pemerintah Indonesia untuk pencapaian target nasional tersebut adalah dengan membiasakan Perilaku Hidup Bersih dan Sehat (PHBS). Berdasarkan hasil Riskesdas 2017 proporsi nasional rumah tangga dengan PHBS baik adalah 32,3\%. Propinsi Jawa Tengah masih merupakan salah satu propinsi yang masih berada di bawah target pelaksanaan PHBS yang baik. Kabupaten Boyolali menjadi bagian dari salah satu kabupaten berkembang di Jawa Tengah. Komposisi masyarakatnya yang majemuk dengan region yang maju menjadikan pembentukan pola kehidupan sehari-harinya beragam. Temuan terkait jamban yang kurang sehat, pengelolaan limbah ternak yang kurang baik hingga mencemari air untuk kebutuhan sehari-hari, pengelolaan sampah rumah tangga yang belum maksimal karena masih banyak ditemukan masyarakat membuang sampah di pekarangan rumah; masih menjadi pekerjaan dari tenaga kesehatan untuk mewujudkan perubahan perilaku kesehatan masyarakat Cabean Kunti, Boyolali ke arah yang lebih sehat. Inovasi pengelolaan limbah rumah tangga dan ternak yang lebih baik serta sehat (LIMBAT) diimplementasikan untuk solusi masalah tersebut.

Tujuan : Penelitian ini bertujuan untuk mengetahui pengaruh LIMBAT terhadap kualitas kesehatan masyarakat pedesaan.

Metode : Penelitian ini merupakan penelitian quasi-experiment dengan rancangan pretest-posttest with control group. Populasi penelitian ini adalah seluruh warga dukuh Rejosari, kelurahan Cabean Kunti, kecamatan Cepogo, kabupaten Boyolali. 114 kepala keluarga menjadi subyek penelitian ini. Peneliti menggunakan kuesioner untuk pengumpulan data, sebelumnya dilakukan uji validitas dan realibilitas. Analisa data dalam penelitian ini menggunakan pairing t-test.

Hasil : Terdapat perubahan kualitas kesehatan antara sebelum perlakuan (pre-test) dan setelah perlakuan (post-test) pada kelompok kontrol $(\mathrm{p}<0.000)$ dan intervensi $(\mathrm{p}<0.000)$. Tidak ada perbedaan antara kelompok intervensi dan kelompok kontrol pada saat sebelum dilakukan intervensi ( $p>0.443$ ). Sedangkan detelah diberikan perlakuan ditemukan adanya perbedaan antara kelompok intervensi dan kelompok kontrol dengan nilai signifikansi $\mathrm{p}>0.000$.
\end{abstract}

Simpulan: Terdapat pengaruh program LIMBAT (Limbah Sehat) terhadap kualitas kesehatan masyarakat pedesaan.

Kata kunci: Limbat, kualitas kesehatan, masyarakat pedesaan. 


\begin{abstract}
Background: Perfect Indonesia Health is on its way to be realized. Perilaku Hidup Bersih dan Sehat (PHBS) is one of the program lauched by the Indonesian government to achieve the national target of health. Based on the Riskesdas in 2019, the national proportion of household with good PHBS is 32.2\%. Central Java provice is still one of the provices in Indonesia that is still under target of good PHBS implementation. Boyolali Regency is part of a developing distric in Central Java. The compositon of the society that is plural with the advanced regions makes the formation of patterns of daily life diverse. Findings related to unhealthy latrines, poor management of livestock waste till pollute water for daily needs, management of household waste that has not optimal yet, because there are still many people found throwing garbage in the yard of the house; these become the responsibility of the health workers to make changes in the health behavior of Cabean Kunti, Boyolali people towards a healthier condition. Innovations for better healthier household and livestock waste management (LIMBAT) are implemented to solve the problem.
\end{abstract}

The Purpose : This study aims to determine the effect of LIMBAT on rural communities.

Method: This study is a quasi-experimental study with a pretest-posttest with control group design. The study population was all residents of the Rejosari, Cabean Kunti, Cepogo, Boyolali. 114 family heads were subjected to this study. Researchers used a questionnaire for data collection, before which a validity and reability test was performed. Data analysis in this study used pairing t-test.

Result: There was a signification differences in health quality before treatment (pre-test) and after treatment (post-test) in control group $(p<0.000)$ and intervention $(p<0.000)$. There was no difference between the intervention group and the control group at the time before the intervention $(p<0.443)$. While after treatment was found, there was a difference between the intervention group and the control group with a significance value of $p>0.000$.

Conclusion: There is a positive effect of the LIMBAT (Healthy Waste) program on the quality of rural community health.

Key words: Limbat, health quality, rural community.

\title{
PENDAHULUAN
}

Indonesia Sehat yang paripurna berada dalam perjalanan dalam realisasinya. Salah satu program yang dicanangkan pemerintah untuk pencapaian target nasional tersebut adalah dengan membiasakan Perilaku Hidup Bersih dan Sehat (PHBS). Program Perilaku Hidup Bersih dan Sehat (PHBS) merupakan bentuk perwujudan untuk memberikan pengalaman belajar atau menciptakan suatu kondisi yang kondusif bagi perorangan, keluarga, kelompok dan masyarakat untuk meningkatkan pengetahuan, sikap dan perilaku agar dapat menerapkan cara-cara hidup sehat dalam rangka menjaga, memelihara, dan meningkatkan kesehatan.

Berdasarkan hasil Riskesdas 2017 proporsi nasional rumah tangga dengan 
PHBS baik adalah 32,3\%. Terdapat 20 Propinsi yang masih memiliki Rumah Tangga dengan PHBS baik dibawah proporsi nasional. Proporsi tertinggi pada DKI Jakarta $(56,8 \%)$ dan terendah pada Papua $(16,4 \%)$. (Kementrian Kesehatan RI, 2017).

Data Riskesdas 2017 di atas menyiratkan bahwa Propinsi Jawa Tengah masih merupakan salah satu propinsi yang masih berada di bawah target pelaksanaan PHBS yang baik. Kabupaten Boyolali menjadi bagian dari salah satu kabupaten berkembang di Jawa Tengah. Komposisi masyarakatnya yang majemuk dengan region yang maju menjadikan pembentukan pola-pola kehidupan sehari-harinya beragam. Berdasar studi pendahuluan yang dilakukan peneliti, Cabean Kunti yang menjadi bagian dari kabupaten Boyolali yang wilayahnya berada cukup jauh dari pusat kota, tetapi beberapa masyarakatnya masih memegang teguh kepercayaan adat dan peninggalan dari leluhur. Keunikan ini dapat dikategorikan sebagai wilayah pedesaan (Gani, Istiaji \& Pratiwi, 2015). Hal ini didukung dengan salah satu kekayaan situs sejarah yang berada di wilayah Cabean Kunti, yaitu Sendang Pitu.

Dalam perjalannya, tenaga kesehatan baik dari pihak swasta dan pemerintah telah berusaha untuk selalu melakukan usaha promotif guna peningkatan kesehatan masyarakat Cabean Kunti. Program PHBS bukan merupakan hal baru yang dipaparkan ke masyarakat Cabean Kunti, Cepogo, Boyolali, Jawa Tengah. Akan tetapi, temuan terkait jamban yang kurang sehat, pengelolaan limbah ternak yang kurang baik hingga mencemari air yang digunakan untuk kebutuhan seharihari, pengelolaan sampah rumah tangga yang belum maksimal karena masih banyak ditemukan masyarakat membuang sampah di pekarangan rumah, serta bak penampungan air yang berpotensi untuk berkembang biak jentik-jentik nyamuk; masih menjadi pekerjaan dari para tenaga kesehatan untuk mewujudkan perubahan perilaku kesehatan masyarakat Cabean Kunti ke arah yang lebih sehat.

Berdasarkan studi pendahuluan dan analisis dari peneliti, maka diusulkanlah kembali program prioritas untuk peningkatan kesehatan masyarakat Cabean Kunti, Cepogo, Boyolali, Jawa Tengah, yaitu melalui dua program unggulan: pengelolaan limbah rumah tangga dan ternak yang lebih baik serta sehat (LIMBAT)

\section{METODE PENELITIAN}

Jenis penelitian ini adalah eksperimen semu (quasi-experiement) dengan rancangan pretest-posttest with control group. Selanjutnya, teknik analisis data yang digunakan adalah regresi linier berganda dengan menggunakan uji $t$, dimana analisis ini dianggap dapat menguraikan hubungan variabel dependen dan independen. Alat ukur yang digunakan oleh peneliti dalam penelitian ini adalah kesioner yang penulis susun sendiri. Kuesioner tersebut dilakukan uji validitas dan reabilitas.

Data yang didapatkan penulis termasuk kategori distribusi data tidak normal sehingga untuk pengujian hipotesis digunakan uji Wilcoxon. Uji Wilcoxon merupakan uji alternatif dari uji pairing t-test apabila tidak memenuhi asumsi normalitas data. 
Selanjutnya untuk mengetahui adakah signifikasi dari intervensi yang diberikan kepada kelompok kontrol dan kelompok intervensi, peneliti menggunakan uji Mann-Whitney. Uji Mann-Whitney dilakukan untuk menguji apakah perbedaan median memiliki makna atau tidak.

\section{HASIL DAN PEMBAHASAN}

Tabel 1. Uji Signifikansi Kualitas Kesehatan Sebelum (Pre-test) \& Sesudah Perlakuan (Post-test) pada Kelompok Kontrol

\begin{tabular}{lc}
\hline & Kategori Post Tes - Kategori Pre Test \\
\hline $\mathrm{Z}$ & $-3.742^{\mathrm{b}}$ \\
Asymp. Sig. (2-tailed) & .000 \\
\hline
\end{tabular}

Dari uji di atas dapat diambil kesimpulan bahwa terdapat perubahan kualitas kesehatan antara sebelum perlakuan (pre-test) dan setelah perlakuan (post-test) pada kelompok kontrol dengan nilai signifikasi $\mathrm{p}<0.000$.

Tabel 2. Uji Signifikansi Kualitas Kesehatan Sebelum (Pre-test) \& Sesudah Perlakuan (Post-test) pada Kelompok Kontrol

\begin{tabular}{lc}
\hline & Kategori Post Tes - Kategori Pre Test \\
\hline $\mathrm{Z}$ & $-6.517^{\mathrm{b}}$ \\
Asymp. Sig. (2-tailed) & .000 \\
\hline
\end{tabular}

Melihat tabel 2 tersebut dapat disimpulkan bahwa terdapat perubahan kualitas kesehatan antara sebelum perlakuan (pre-test) dan setelah perlakuan (post-test) pada kelompok intervensi dengan nilai signifikansi $\mathrm{p}<0.000$.

Setelah dilakukan uji Wilcoxon pada kedua kelompok yaitu kelompok kontrol dan kelompok intervensi, selanjutnya dilakukan Uji Mann-Whitney untuk mengetahui perbedaan antara kelompok intervensi dan kelompok kontrol sebelum diberikan perlakuan sebelum (pre-test) dan sesudah perlakuan (post-test).

Tabel 3. Uji Signifikansi Kualitas Kesehatan Sebelum (Pre-test) \& Sesudah Perlakuan (Post-test) pada Kelompok Kontrol

\begin{tabular}{lcc}
\hline & Kategori Pre Test & Kategori Post Tes \\
\hline Mann-Whitney U & 1519.000 & 594.000 \\
Wilcoxon W & 3172.000 & 2247.000 \\
Z & -.767 & -7.109 \\
Asymp. Sig. (2-tailed) & .443 & .000 \\
\hline
\end{tabular}

Dari hasil tersebut didapatkan bahwa tidak ada perbedaan antara kelompok intervensi dan kelompok kontrol pada saat sebelum diberikan perlakuan (pre-test), dengan nilai signifikansi $\mathrm{p}>0.443$. Selanjutnya dapat disimpulkan juga bahwa terdapat perbedaan antara kelompok intervensi dan kelompok kontrol setelah diberikan perlakuan (post-test) dengan nilai signifikansi $\mathrm{p}>0.000$.

Penelitian ini menunjukkan bahwa perlakuan yang diberikan berupa Program Limbah Sehat (LIMBAT) memberikan peningkatan terhadap kualitas kesehatan. Program LIMBAT dilakukan dengan melalui tiga tahap yaitu sosialisasi, aplikasi dan evaluasi. Pada tahap sosialisasi diberikan pemahaman 
pentingya mengelola limbah ternak dimana sebagian besar warga memiliki hewan ternak dan dibuatkan kandang tidak jauh dari rumah.

Limbah ternak tersebut berisiko mencemari lingkungan, seperti air dan udara. Karenanya perlu dilakukan pengelolaan dengan cara membuat saluran pembuangan air limbah. Dari perlakuan tersebut, didapatkan hasil yang efektif. Hal ini seperti yang ditemukan pada penelitian yang dilakukan oleh Wardana, dkk (2015) dimana skenario dari penelolaan limbah rumah tangga terbukti efektif untuk peningkatan kesehatan masyarakat.

Pengelolaan limbah yang baik juga mendukung peningkatan kesehatan secara umum dengan ditandai bahwa angka kesakitan masyarakat menurun dan merasa tidak ada pembatasan aktivitas sehari-hari (Nilasari dkk, 2016). Pengelolaan air limbah di pedesaan khususnya di Desa Cempogo, yang dikelola masyarakat yang sederhana mampu membantu masyarakat dalam meningkatkan status kesehatannya. Hastusi dan Agustien (2013) menambahkan dalam penelitiannya bahwa instalasi pengelolaan air limbah dilakukan dengan penerapan sistem biofilm anaerobik yaitu dengan media jaring ikan dan batok kelapa dilanjutkan dengan constructed wetland. Kombinasi ini memberikan hasil yang maksimal untuk pengelolaan limbah.

\section{SIMPULAN DAN SARAN}

\section{Simpulan}

Beberapa kesimpulan yang dapat diambil dari penelitian ini antara lain: 1) Terdapat perubahan kualitas kesehatan antara sebelum perlakuan (pre-test) dan setelah perlakuan (post-test) pada kelompok intervensi, 2) Terdapat perubahan kualitas kesehatan antara sebelum perlakuan (pre-test) dan setelah perlakuan (post-test) pada kelompok kontrol, 3) Tidak ada perbedaan antara kelompok intervensi dan kelompok kontrol sebelum diberikan perlakuan (pre-test), 4) Terdapat perbedaan antara kelompok intervensi dan kelompok kontrol pada saat diberikan perlakukan (post-test).

\section{Saran}

Output dari penelitian ini diharapkan dapat memperkaya evidence based untuk menunjang pengayaan materi perkuliahan dan diharapkan mampu menjadi poin penting dalam penyusunan buku ajar atau modul pembelajaran keperawatan. Evidence yang dimunculkan dalam penelitian ini dapat diangkat aplikasinya dalam praktik keperawatan di komunitas, Inovasi implementasi berupa program LIMBAT (Limbah Sehat) harapannya mampu memberikan perubahan dalam perilaku hidup sehat sehari-hari di komunitas serta mampu memberikan luaran kualitas kesehatan masyarakat yang lebih baik.

Luaran dari penelitian ini dalam jangka menengah diharapkan mampu memberikan sumbangsih dalam penguatan program pemerintah daerah dalam merealisasikan PHBS untuk Indonesia Sehat yang paripurna. Dalam jangka panjang, luaran penelitian ini mampu memberikan andil dalam penyusunan kebijakan pemerintah untuk agenda nasional menuju Indonesia Sehat paripurna. 


\section{DAFTAR PUSTAKA}

Apriyani, Umniyati, S.R., Sutomo, A.H. 2016. Sanitasi lingkungan dan keberadaan jentik Aedes sp dengan kejadian demam berdarah dengue di Banguntapan Bantul. BKM Journa of Community Medicine and Public Health, 33(2): 79-84. Diakses dari: https://media.neliti.com/media/publications/238002-keberadaan-jentikdan-kejadian-demam-ber-33154f19.pdf

Dewi, S. 2018. Pelayanan kesehatan dan hubungannya dengan peningkatan kualitas kesehatan. Diakses dari: http://lib.ui.ac.id/file?file=digital/122785S09044fk-Hubungan\%20profil-Literatur.pdf

Hastuti, E., Agustien, R.R. 2013. Daur ulang air limbah rumah tangga dengan teknologi biofilter dan hybrid constructed wetland di kawasan pesisir. Jurnal Pemukiman, 8(3): 136-144. Diakses dari: https://www.researchgate.net/publication/324908591_DAUR_ULANG_A IR_LIMBAH_RUMAH_TANGGA_DENGAN_TEKNOLOGI_BIOFILT ER_DAN_HYBRID_CONSTRUCTED_WETLAND_DI_KAWASAN_P ESISIR_Domestic_Wastewater_Reuse_by_Using_Biofilter_Technology_a nd_Hybrid_Constructed_Wetland_i

Mubraokah, R., Indarjo, S. 2013. Upaya peningkatan Angka Bebas Jentik (ABJ) melalui penggerakan jumantik. Unnes Journal of Public Health, 2(3): 1-9. Diakses dari: https://journal.unnes.ac.id/sju/index.php/ujph/article/view/5966/4639

Nilasari, E., Faizal, M., Suheryanto. 2016. Pengolahan air limbah rumah tangga dengan menggunakan proses gabungan saringan bertingkat dan bioremediasi eceng gondok (Eichornia crassipes): Studi kasus di perumahan Griya Mitra 2, Palembang. Jurnal Penelitian Sains, 18(1): 18102-8 - 18102-13. Diakses dari: https://media.neliti.com/media/publications/168089-ID-pengolahan-airlimbah-rumah-tangga-denga.pdf

Santi, D., Budiono, I., Wahyono, B. 2015. Faktor yang berhubungan dengan keberadaan jentik aedes aegypti (studi kasus di kelurahan Sukorejo, kecamatan Gunungpati, kota Semarang tahun 2014). Unnes Journal of Public Health, 4(1): 69-75.

Sari, P.N. 2017. Analisis pengelolaan sampah padat di kecamatan Banuhampu kabupaten Agam. Diakses dari: https://www.researchgate.net/publication/319398619_ANALISIS_PENGE LOLAAN_SAMPAH_PADAT_DI_KECAMATAN_BANUHAMPU_KA BUPATEN_AGAM/download

Subekti, S. 2009. Pengelolaan limbah cair rumah tangga. Diakses dari: https://jurnal.unpand.ac.id/index.php/dinsain/article/viewFile/140/137

Sulistyarini, Hargono, R. 2018. Hubungan perilaku hidup sehat dengan status kesehatan masyarakat kelurahan Ujung. Diakses dari: https://www.researchgate.net/publication/328286431_HUBUNGAN_PER ILAKU_HIDUP_SEHAT_DENGAN_STATUS_KESEHATAN_PADA_ MASYARAKAT_KELURAHAN_UJUNG 
Sunarsih, E. 2014. Konsep pengolahan limbah rumah tangga dalam upaya pencegahan pencemaran lingkungan. Jurnal Ilmu Kesehatan Masyarakat, 5(3): 162-167. Diakses dari: https://media.neliti.com/media/publications/57961-ID-concept-ofhousehold-waste-in-environmen.pdf

Suyanto, E., Soetarto, E, Sumardjo, Hardjomidjojo, H. 2015. Model kebijakan pengelolaan sampah berbasis partisipasi "Green Community" mendukung kota hijau. MIMBAR, 3II(1): 143-152. Diakses dari: https://media.neliti.com/media/publications/7519-ID-model-kebijakanpengelolaan-sampah-berbasis-partisipasi-green-community-mendukun.pdf

Wardana, Y.N., Syafrudin, Rexagama, A. 2015. Sistem perencanaan pengelolaan sampah B3 rumah tangga di kecamatan Semarang Barat, kota Semarang. Junral Teknik Lingkungan, 4(3): 1-12. Diakses dari: https://media.neliti.com/media/publications/141681-ID-sistemperencanaan-pengelolaan-sampah-b3.pdf

Wulansari, G. 2018. Hubungan sanitasi dan nutrisi terhadap peningkatan kesehatan. Diakses dari: http://digilib.unila.ac.id/4491/12/BAB\%20II.pdf

Yazid, F. 2013. Kualitas individu dan hubungannya dengan pemberdayaan masyarakat. Diakses dari: http://eprints.ums.ac.id/24022/3/05._BAB_II.pdf 